\title{
Identification of Staphylococcus aureus genes expressed during growth in milk: a useful model for selection of genes important in bovine mastitis?
}

\author{
Aart Lammers, Ellard Kruijt, Corine van de Kuijt, Piet J. M. Nuijten† \\ and Hilde E. Smith
}

Department of Bacteriology, Institute for Animal Science and Health, PO Box 65, 8200 AB Lelystad, The Netherlands

\author{
Author for correspondence: Aart Lammers. Tel: +31320 238403. Fax: + 31320238153. \\ e-mail: a.lammers@id.wag-ur.nl
}

\begin{abstract}
Staphylococcus aureus is a major cause of bovine mastitis. Since gene expression of many bacteria is known to be regulated by the environment, milk may play an important role in the regulation of the early steps in the pathogenesis of bovine mastitis by $S$. aureus. To get insight into the response of $S$. aureus to the milk environment, a Tn917-lacZ mutant library was generated and screened for genes specifically expressed during growth in milk. Twenty-eight mutants were identified and analysed. Four groups of genes were found, involved in cell-wall synthesis, nucleotide synthesis, transcriptional regulation and carbohydrate metabolism. A fifth group contained genes with hypothetical or unknown functions. Many of the genes identified belonged to biosynthetic pathways of $S$. aureus and other bacterial species which have also been shown to play a role in vivo as determined in murine infection models. Therefore, growth on milk may be an attractive model for the identification of genes preferentially expressed during bovine mastitis.
\end{abstract}

Keywords: gene expression, mastitis, Tn917-lacZ, Staphylococcus aureus

\section{INTRODUCTION}

Staphylococcus aureus is the most important causative agent of bovine mastitis, causing considerable economic losses in the dairy industry. The majority of the infections are subclinical, but the number of clinical cases is increasing. S. aureus infections are mainly treated with antibiotics, but such treatment is often unsuccessful. Therefore, new anti-staphylococcal therapies based on novel approaches are required. More knowledge about $S$. aureus gene expression during infection of the mammary gland will be helpful for that purpose.

It has been shown that bacteria, including $S$. aureus,

\footnotetext{
† Present address: Intervet International BV, PO Box 31, 5830 AA Boxmeer, the Netherlands.

Abbreviations: $\beta$-gal, $\beta$-galactosidase; IVET, in vivo expression technology; STM, signature-tagged mutagenesis.

The GenBank accession numbers for the sequences determined in this work are AF223893-AF223920.
}

respond to the complex in vivo environment by altering their gene expression (Finlay \& Falkow, 1997; Lowe et al., 1998). When $S$. aureus enters the mammary gland through the teat canal the bacteria are confronted with changing environmental conditions. Within a few hours of intramammary infusion of less than $100 \mathrm{~S}$. aureus cells, large numbers of bacteria can be detected in the milk (Sutra \& Poutrel, 1994). This suggests that S. aureus can easily adapt to, survive in and replicate in the bovine mammary gland. The ability of $S$. aureus to replicate rapidly in the mammary gland is considered to be important for establishing an infection. Because it is generally believed that replication of $S$. aureus takes place in close contact with milk, several investigators have studied growth of $S$. aureus in milk or milk whey in vitro. Densities of $10^{8}$ c.f.u. $\mathrm{ml}^{-1}$ can be reached easily (Fang et al., 1993). S. aureus cells grown in milk or milk whey in vitro become resistant to phagocytosis (Sutra et al., 1990; Sandgren et al., 1991) and show increased virulence in a mouse model (Mamo et al., 1991), suggesting that a different set of genes becomes expressed during growth in milk. However, no infor- 
mation is available on gene expression during growth in milk.

In order to identify genes that are specifically expressed during growth in milk, we generated a mutant library of S. aureus containing Tn917-lacZ insertions (Cheung et al., 1992). The transposon Tn917-lacZ contains a promoterless lac $Z$ gene as a reporter gene, so that $\beta$ galactosidase ( $\beta$-gal) expression is dependent on transcriptional fusions between $S$. aureus chromosomal promoters and the lac $Z$ gene. The $S$. aureus transposon library was screened during growth on bovine milk and mutants were selected which expressed $\beta$-gal in milk but not in nutrient-rich growth media. In this way we have identified 28 S. aureus genes. Many of the genes identified belong to the same biosynthetic pathways as genes which were identified by in vivo approaches in various murine infection models (Mei et al., 1997; Coulter et al., 1998; Lowe et al., 1998).

\section{METHODS}

Bacterial strains, growth conditions and plasmid. S. aureus strain RN4220 was obtained from J. M. Patti (Centre for Extracellular Matrix Biology, Houston, TX, USA). Escherichia coli strains DH5 $\alpha$ (Clontech) and XL2blue (Stratagene) were used for plasmid transformations and preparation of plasmid. S. aureus and E. coli strains were grown in Luria-Bertani (LB) medium (Sambrook et al., 1989) and on LB agar. When required, erythromycin (Erm, $10 \mu \mathrm{g}$ $\mathrm{ml}^{-1}$ ), tetracycline (Tet, $\left.10 \mu \mathrm{g} \mathrm{ml}^{-1}\right)$ and ampicillin $\left(50 \mu \mathrm{g} \mathrm{ml}^{-1}\right)$ were added to the media.

Two types of growth media were used for screening the $S$. aureus Tn917-lacZ transposon library. LB agarose plates contained LB with $1.5 \%(\mathrm{w} / \mathrm{v})$ agarose (Boehringer Mannheim), $0 \cdot 5 \%$ (w/v) glucose, $250 \mu \mathrm{g} \mathrm{X-Gal} \mathrm{ml}{ }^{-1}$ and $10 \mu \mathrm{g}$ Erm ml ${ }^{-1}$. Milk agarose plates contained fresh bovine milk, $1.5 \%(\mathrm{w} / \mathrm{v})$ agarose, $0.5 \%(\mathrm{w} / \mathrm{v})$ glucose, $0.5 \%(\mathrm{w} / \mathrm{v})$ casein enzymic hydrolysate (Casamino acids, Sigma), $250 \mu \mathrm{g} \mathrm{X-Gal}$ $\mathrm{ml}^{-1}$ and $10 \mu \mathrm{g} \mathrm{Erm} \mathrm{ml}^{-1}$. Prior to the preparation of the plates, the milk was incubated for $1 \mathrm{~h}$ at $80^{\circ} \mathrm{C}$. Nine volumes of the milk were mixed with one volume of a $15 \%(\mathrm{w} / \mathrm{v})$ agarose solution. To this solution glucose, Casamino acids, X-Gal and Erm were added. Glucose was added to the media to prevent endogenous $\beta$-gal expression by $S$. aureus. The Casamino acids were added to prevent selection of genes involved in biosynthesis of amino acids.

Plasmid pLTV1 (Camilli et al., 1990) was obtained from P. Youngman (University of Georgia).

Preparation of milk whey. Fresh bovine milk was centrifuged for $30 \mathrm{~min}$ at $13000 \mathrm{~g}$. After removal of the fat layer, $40 \mu \mathrm{g}$ $\mathrm{ml}^{-1}$ rennin (Rademaker BV, The Netherlands) was added and the solution was incubated for $2 \mathrm{~h}$ at $37^{\circ} \mathrm{C}$ and centrifuged twice for $30 \mathrm{~min}$ at $13000 \mathrm{~g}$. The supernatant was subsequently sterilized through a $0.45 \mu \mathrm{m}$ Millipore filter and stored at $-20{ }^{\circ} \mathrm{C}$.

Generation of the S. aureus Tn917-lacZ library. Plasmid pLTV1 was transformed to $S$. aureus strain RN4220 by electroporation (Schenk \& Laddaga, 1992). Transformed cells were selected at $30^{\circ} \mathrm{C}$ on LB agar plates containing Tet $(10 \mu \mathrm{g}$ $\left.\mathrm{ml}^{-1}\right)$. Subsequently, the colonies were suspended in $10 \mathrm{ml} \mathrm{LB}$ with $2 \mu \mathrm{g} \mathrm{Erm} \mathrm{ml^{-1 }}$ to a density of $10^{10}$ bacteria $\mathrm{ml}^{-1}$ and incubated for $6 \mathrm{~h}$ at $43^{\circ} \mathrm{C}$ in a shaking waterbath. Then, the suspension was transferred to $100 \mathrm{ml} \mathrm{LB}$ containing $5 \mu \mathrm{g}$ Erm $\mathrm{ml}^{-1}$ and incubated overnight at $43{ }^{\circ} \mathrm{C}$ in a shaking waterbath. One hundred millilitres of the overnight culture was diluted

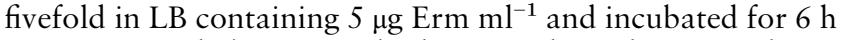
at $43{ }^{\circ} \mathrm{C}$ in a shaking waterbath. From this culture $10 \mathrm{ml}$ was diluted 80-fold in LB containing $5 \mu \mathrm{g} \mathrm{Erm} \mathrm{ml}^{-1}$ and incubated overnight in a shaking waterbath of $43^{\circ} \mathrm{C}$. Aliquots of this culture were stored at $-70{ }^{\circ} \mathrm{C}$.

Screening of the $\boldsymbol{S}$. aureus library. The $S$. aureus library was plated on milk agar plates and individual colonies were plated on LB or milk agarose plates. Colonies that were white on LB and blue (pale to dark blue) on plates containing milk were selected. All selected mutants were rescreened and characterized further.

Cloning and sequencing of $S$. aureus DNA sequences upstream of Tn917-lacZ insertions. Cloning of DNA located upstream of the transposon insertion was essentially done as described by Camilli et al. (1990). Chromosomal DNA of $S$. aureus RN4220 mutants was cut with EcoRI, ligated and used to transform E. coli DH5 $\alpha$ or XL2blue cells. Plasmid DNA for sequencing was isolated using the Wizard plus SV miniprep DNA purification system (Promega). DNA sequences were determined by a 373A DNA Sequencing System (Applied Biosystems). Samples were prepared by use of an ABI/PRISM dye termination cycle sequencing ready reaction kit (PerkinElmer). Sequence data were assembled and analysed using the BLASTX program (Altschul et al., 1990). The primer used in the sequencing reactions was 5'-CACAATAGAGAGATGTCACCG $-3^{\prime}$ and corresponded to position 84-104 in the Tn917 sequence.

Southern blotting and hybridization. Chromosomal DNA of $S$. aureus was isolated essentially as described by Sambrook et al. (1989). To lyse the $S$. aureus cells, lysozyme was replaced by lysostaphin $\left(10 \mu \mathrm{g} \mathrm{ml}^{-1}\right.$; Sigma). Southern blot analysis of transposon insertions in the $S$. aureus chromosome was performed using the pLTV1 plasmid as a probe. Labelling of the probe and hybridization of the blots was essentially done as previously described (Smith et al., 1995).

Phage transduction. The transposons of the selected mutants were transferred to the $S$. aureus strain 8325-4 background using the transducing phage $\phi 85$ as described by Novick (1991). The transductants were selected for Erm resistance. To discriminate the original RN4220 mutant from the transduced 8325-4 mutant, the haemolytic phenotype was determined on agar plates containing $5 \%$ washed bovine red blood cells. Three individual transductants of each mutant were tested for expression of the lac Z gene on LB and milk plates.

Growth analysis of transduced mutants. The growth rate of the selected mutants was determined by measuring the increase in the $\mathrm{OD}_{600}$. Overnight cultures in LB or milk whey were diluted $1 / 50$ in LB or milk whey in microtitre plates. The microtitre plates were incubated at $37^{\circ} \mathrm{C}$ and the $\mathrm{OD}_{600}$ was measured as a function of time in a microplate reader. The growth rate of mutants that were impaired in their ability to grow was redetermined using $100 \mathrm{ml}$ cultures in Erlenmeyer flasks.

$\boldsymbol{\beta}$-Gal expression in liquid milk whey. $\beta$-Gal assays were performed using the chemiluminescent $\beta$-Gal Reporter Gene Assay (Boehringer Mannheim). Briefly, $1 \mathrm{ml}$ aliquots of $S$. aureus cells grown in milk whey or LB were sampled as a function of time, centrifuged for $10 \mathrm{~min}$ at $3000 \mathrm{~g}$ and washed once in ice cold PBS $(0 \cdot 01 \mathrm{M}, \mathrm{pH} 7 \cdot 2)$. The pellets were frozen at $-20^{\circ} \mathrm{C}$ for later analysis. The frozen cell samples were thawed and lysed in $200 \mu \mathrm{l}$ lysis buffer containing $20 \mu \mathrm{g}$ 
lysostaphin $\mathrm{ml}^{-1}$ for $30 \mathrm{~min}$ at $37^{\circ} \mathrm{C}$. Samples of $50 \mu \mathrm{l}$ were tested in the chemiluminescent assay in triplicate. The reaction time was carried out for $60 \mathrm{~min}$ at room temperature in white 96-well microtitre plates (Greiner). Chemiluminescent signals were detected in a Victor 1420 multilabelcounter (Wallac Oy). $\beta$-Gal activity was expressed as counts per second (c.p.s.) per $\mathrm{OD}_{600}$ unit.

\section{RESULTS AND DISCUSSION}

\section{Construction of the transposon library}

The objective of our study was the screening of a mutant $S$. aureus library for expression of lac $Z$ under the control of $S$. aureus promoters. To construct such a library, we selected an $S$. aureus strain which is able to persist and replicate in the udder and which is able to express lac Z in a way that results in blue colonies on XGal plates. S. aureus strain RN4220 induced an inflammatory response and the bacteria persisted and replicated in the mammary gland for at least several days (data not shown). Therefore, strain RN4220 was used for the construction of the Tn917-lacZ library. To determine the transposition frequency the library was plated on plates containing Erm or Tet. Over $99 \%$ of the cells were Erm resistant and Tet sensitive, indicating the insertion of the transposon into the chromosome and the loss of pLTV1. Southern blotting and hybridization experiments showed that 14 out 18 mutants analysed had insertions at unique positions (results not shown). Four mutants showed identical hybridization patterns, indicating the presence of at least one hot spot. As well as hot spots, hot-spot regions have also been found by Tn917 insertions in Gram-positive bacteria (Youngman, 1987; Camilli et al., 1990). The presence of these hotspot regions in S. aureus cannot be excluded, but broad coverage of the genome by Tn917 insertions has been reported (Coulter et al., 1998). Based on our data, the Tn917 library seemed to contain enough variation to allow the identification of various differentially expressed $S$. aureus genes during growth in milk.

\section{Identification of milk-induced genes}

An appropriate dilution of the transposon library was plated on milk agarose plates containing X-Gal. About 150 blue colonies were selected and plated on LB and milk agarose plates. Transposon mutants showing increased levels of $\beta$-gal expression on plates containing milk were selected and rescreened on the two different growth media. Finally, 28 mutants were selected and characterized further. The colour of the selected colonies on milk plates containing X-Gal varied from pale blue to dark blue, indicating that the different mutants had various levels of $\beta$-gal expression. $\beta$-Gal activities on milk plates and milk whey plates were comparable (results not shown).

S. aureus strain RN4220 is chemically mutagenized. To exclude the possibility that secondary mutations elsewhere on the genome of this strain had an effect on $\beta$-gal expression, bacteriophage $\phi 85$ was used to transduce the
Tn917-lacZ insertions into S. aureus strain 8325-4. The transductants were subsequently tested for their $\beta$-gal activity (Table 1). No major differences were observed between the $\beta$-gal activity of the 8325-4 transductants (designated SMI01T to SMI43T) and the original RN4220 mutants (designated SMI01 to SMI43; results not shown). This strongly indicates that the genes selected in strain RN4220 are induced by environmental conditions and are not the result of secondary mutations in the genome of this strain.

In the primary selection, glucose was added to prevent expression of endogenous $S$. aureus genes encoding $\beta$-gal (Oskouian \& Stewart, 1990). Moreover, Casamino acids were added to prevent the selection of genes involved in amino acid biosynthesis. However, since both glucose and Casamino acids may affect the bacterial gene expression (Ohlsen et al., 1997; Chan \& Foster, 1998), we subsequently determined the $\beta$-gal activity of the selected mutants on LB and milk plates without glucose and Casamino acids. No effects of glucose and Casamino acids on $\beta$-gal expression were observed (results not shown). This indicates that the expression of the genes selected in this study was not regulated by glucose or Casamino acids.

\section{$\beta$-Gal activities in liquid milk whey and LB}

We next tested whether the differences in $\beta$-gal expression observed on plates could also be measured after growth in liquid media. For this purpose, we measured $\beta$-gal activities in liquid milk whey and LB. The majority of the mutants $(23 / 28)$ showed enhanced $\beta$-gal activities after growth in milk whey compared to growth in LB (Table 1). In five mutants the differences between $\beta$-gal expression were more pronounced after growth on plates than after growth in liquid media. This may be due to the type of growth medium (solid vs liquid) or the growth phases in which the $\beta$-gal activity was determined (colonies vs exponential-phase cultures).

\section{Growth rate of the selected mutants in milk whey}

To investigate whether the transposon insertions affected the ability to grow in milk whey, overnight cultures of the mutant strains in LB or milk whey were diluted in LB medium and milk whey and incubated in microtitre plates at $37^{\circ} \mathrm{C}$. The $\mathrm{OD}_{600}$ was measured as a function of time. All 28 mutants showed the same growth rate in LB medium. However, three mutants showed a reduced growth rate in milk whey. This was confirmed by culturing in Erlenmeyer flasks (Fig. 1a). Sequence analysis (see below) showed that these mutants were impaired in their purine biosynthetic pathway. The addition of $1.0 \mathrm{mM}$ adenine to milk whey partly restored the growth rate of the mutants SMI05T (identical to SMI32T) and SMI06T (Fig. 1a) and reduced the expression of $\beta$-gal (15- and 25 -fold, respectively; Fig. 1b). Similar results were obtained by Klarsfeld et al. (1994) for Listeria monocytogenes, in which insertional inactivation of pur genes also inhibited growth in a defined 
Table 1. Milk-expressed S. aureus genes

\begin{tabular}{|c|c|c|c|c|c|c|c|}
\hline \multirow[t]{2}{*}{ Gene class } & \multirow[t]{2}{*}{ Mutant* } & \multirow[t]{2}{*}{ Similar to $\dagger$} & \multirow{2}{*}{$\begin{array}{l}\text { Percentage } \\
\text { identity } \\
\text { (positives) }\end{array}$} & \multicolumn{2}{|c|}{$\begin{array}{l}\beta \text {-Gal activity } \\
\text { on: }\end{array}$} & \multirow{2}{*}{$\begin{array}{l}\text { Ratio of } \\
\beta \text {-gal } \\
\text { activity } \neq\end{array}$} & \multirow{2}{*}{$\begin{array}{c}\text { Presumed function, } \\
\text { SWISS-PROT TREMBL } \\
\text { numbers and PROSITE motifs }\end{array}$} \\
\hline & & & & $\begin{array}{l}\text { LB } \\
\text { plates }\end{array}$ & $\begin{array}{l}\text { Milk } \\
\text { plates }\end{array}$ & & \\
\hline \multirow[t]{7}{*}{$\begin{array}{l}\text { I. Peptidoglycan/lysine } \\
\text { biosynthesis }\end{array}$} & $\begin{array}{l}\text { SMI01T, } \\
\text { SMI08T }\end{array}$ & $l y s A(B s u)$ & $41(59)$ & - & + & 2 & $\begin{array}{l}\text { Lysine biosynthesis/peptidoglycan } \\
\text { biosynthesis }\end{array}$ \\
\hline & SMI09T & asd $(B s u)$ & $50(69)$ & - & + & 7 & $\begin{array}{l}\text { Lysine biosynthesis/peptidoglycan } \\
\text { biosynthesis }\end{array}$ \\
\hline & SMI26T & asd $(B s u)$ & $53(71)$ & - & + & 12 & $\begin{array}{l}\text { Lysine biosynthesis/peptidoglycan } \\
\text { biosynthesis }\end{array}$ \\
\hline & SMI13T & lysC $(M t u)$ & $43(59)$ & - & ++ & 54 & $\begin{array}{l}\text { Lysine biosynthesis/peptidoglycan } \\
\text { biosynthesis }\end{array}$ \\
\hline & SMI29T & $\operatorname{dapA}(M j a)$ & $35(51)$ & - & + & 9 & $\begin{array}{l}\text { Lysine biosynthesis/peptidoglycan } \\
\text { biosynthesis }\end{array}$ \\
\hline & SMI12T & $\mathrm{femB}(\mathrm{Sau})$ & $98(98)$ & + & ++ & 1 & Peptidoglycan cross-linking \\
\hline & SMI18T & murZ $(B s u)$ & $43(59)$ & $+/-$ & + & 2 & Peptidoglycan biosynthesis \\
\hline \multirow[t]{4}{*}{ II. DNA biosynthesis } & $\begin{array}{l}\text { SMI05T, } \\
\text { SMI32T }\end{array}$ & purH $(B c e)$ & $60(80)$ & - & ++ & 1250 & Purine biosynthesis \\
\hline & SMI06T & yexA $(B s u)$ & $33(64)$ & - & ++ & 1117 & Purine biosynthesis, P12049 \\
\hline & SMI20T & purD (Hpy) & $38(59)$ & - & ++ & 196 & Purine biosynthesis \\
\hline & SMI07T & pyrP $(B c a)$ & $56(66)$ & - & ++ & 18 & Uracil permease \\
\hline \multirow[t]{2}{*}{$\begin{array}{l}\text { III. Transcriptional } \\
\text { regulators }\end{array}$} & SMI02T & phoR (Bsu) & $51(72)$ & - & ++ & 1 & $\begin{array}{l}\text { Histidine phosphokinase, } \\
\text { regulation gene expression under } \\
\text { phosphate-limiting conditions }\end{array}$ \\
\hline & SMI33T & $\operatorname{comK}(B s u)$ & $43(62)$ & - & ++ & 12 & $\begin{array}{l}\text { Transcriptional regulation of } \\
\text { genetic competence }\end{array}$ \\
\hline $\begin{array}{l}\text { IV. Carbohydrate } \\
\text { metabolism }\end{array}$ & SMI15T & $\begin{array}{l}\text { F45e1.3 } \\
\quad(\text { Cel })\end{array}$ & $32(54)$ & - & + & 3 & Carbon metabolism, U28732 \\
\hline \multirow[t]{11}{*}{ V. Hypothetical genes } & $\begin{array}{l}\text { SMI44T, } \\
\text { SMI46T }\end{array}$ & $\begin{array}{r}\text { Staphopain } \\
\text { gene }(\text { Sau })\end{array}$ & $47(66)$ & - & ++ & 1680 & $\begin{array}{l}\text { Hypothetical thiol-induced } \\
\text { protease P81297, PS00639 }\end{array}$ \\
\hline & SMI019T & $y k d(B s u)$ & $46(72)$ & + & + & $1 \cdot 6$ & $\begin{array}{l}\text { Unknown, hypothetical } 23 \cdot 6 \mathrm{kDa} \\
\text { protein, P94357 }\end{array}$ \\
\hline & SMI04T & None & & - & + & 5 & Unknown \\
\hline & SMI016T & None & & - & + & 1 & Unknown \\
\hline & SMI017T & None & & - & + & 2 & Unknown \\
\hline & SMI035T & None & & - & + & 16 & Unknown \\
\hline & SMI040T & None & & - & + & 10 & Unknown \\
\hline & SMI024T & None & & $+/-$ & + & 1 & Unknown \\
\hline & SMI025T & None & & + & ++ & 1 & Unknown \\
\hline & SMI027T & None & & - & ++ & 14 & Unknown \\
\hline & SMI043T & None & & - & ++ & 90 & Unknown \\
\hline
\end{tabular}

*Sequence analysis was done with cloned DNA from the initial RN4220 mutants. $\beta$-Gal activity was determined with transductants of strain 8325-4.

†Bsu, Bacillus subtilis; Mtu, Mycobacterium tuberculosis; Mja, Methanococcus jannaschii; Sep, Staphylococcus epidermidis; Bce, Bacillus cereus; Hpy, Helicobacter pylori; Bca, Bacillus caldolyticus; Ech, Erwinia chrysanthemi; Cel, Caenorhabditis elegans; Sau, Staphylococcus aureus.

$\neq$ Induction is expressed as the ratio of $\beta$-gal activity of bacteria cultured to $\mathrm{OD}_{600} 0.5$ in milk whey to that of bacteria cultured to $\mathrm{OD}_{600}$ $0 \cdot 5$ in LB medium. The cells of strains SMI05T, SMI06T and SMI032T were harvested at an $\mathrm{OD}_{600}$ of approximately $0 \cdot 15$.

medium. However, in that study the addition of adenine had a more pronounced effect on the growth rate and the $\beta$-gal activity. Mutant SMI20T, mutagenized in the purD gene, showed no reduced growth rate in milk whey, but the addition of adenine reduced the $\beta$-gal activity eightfold (Fig. 1b). As a control the effect of adenine on the $\beta$-gal activity of mutant SMI07T was determined (Fig. 1b). This mutant, mutagenized in the pyrP gene encoding a pyrimidine transporter, showed no decreased $\beta$-gal expression after addition of adenine. 

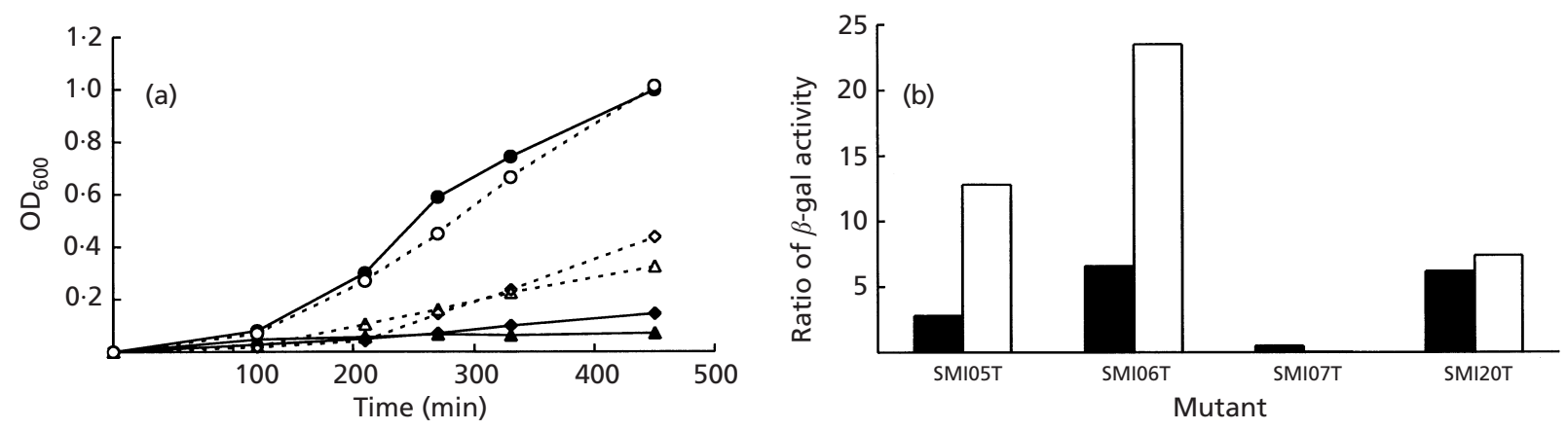

Fig. 1. Effect of adenine on the growth rate (a) and $\beta$-gal activity (b) of $S$. aureus strains. (a) Growth rates of strains SMI05T (triangles), SMI06T (diamonds) and 8325-4 (circles) in milk whey without adenine (solid lines and closed symbols) or in milk whey with $1 \mathrm{mM}$ adenine (dashed lines and open symbols). (b) $\beta$-Gal activity of bacteria cultured for 210 (solid bars) and 330 (open bars) $\mathrm{min}$ at $37^{\circ} \mathrm{C}$ in milk whey without adenine expressed as a ratio relative to the $\beta$-gal activity with adenine.

\section{Cloning and sequence analysis of flanking chromosomal DNA regions}

Southern blotting experiments of EcoRI-digested chromosomal DNAs of the selected mutants, probed with the pLTV1 vector, showed that all mutant strains contained a single transposon insertion (data not shown). Chromosomal DNA regions flanking the lacZproximal end of the transposon were cloned in E. coli. The plasmids were isolated and the upstream flanking DNA regions were sequenced. For each clone approximately 300 bp of sequence was obtained. The sequences were analysed for homology to genes present in data libraries, and were classified based on the (hypothetical) functions of the genes (Table 1).

I. The first class, of eight mutants, comprised insertions in genes with homology to genes involved in lysine and/or peptidoglycan synthesis. Lysine is present in proteins as well as in the tetrapeptide cross-bridges of the cell wall peptidoglycan of $S$. aureus (Seligman \& Pincus, 1987). lys A encodes diaminopimelate decarboxylase and is involved in the conversion of diaminopimelate to lysine (Wehrmann et al., 1998). S. aureus asd and $l y s A$ genes were also identified after using STM in murine infection models (Mei et al., 1997; Coulter et al., 1998). This means that mutations in genes of this pathway cause attenuation in vivo. Mutant SMI12T contained a transposon insertion in the $f e m B$ gene of $S$. aureus (Berger-Bachi et al., 1992). The $f e m B$ gene is involved in formation of the peptidoglycan pentaglycine cross-bridges (Ehlert et al., 1997). femB was also identified by STM, and femB knockout mutants were strongly attenuated in murine infection models (Mei et al., 1997; Coulter et al., 1998). Mutant SMI18 contained a transposon insertion in a gene that shares homology to murZ of Bacillus subtilis, which is also involved in peptidoglycan synthesis (Marquardt et al., 1992). After using IVET an $S$. aureus gene homologous to murC of $B$. subtilis was identified; this gene was induced in a murine infection model (Lowe et al., 1998). The murC gene is also involved in peptidoglycan biosynthesis. Both IVET and STM studies showed that $S$. aureus genes involved in peptidoglycan synthesis play a role in vivo as determined in murine infection models. By selecting for $S$. aureus genes specifically expressed on milk, genes that may be involved in peptidoglycan biosynthesis were selected with a relatively high frequency $(6 / 25)$. This suggests that enhanced expression of genes involved in peptidoglycan biosynthesis is required for growth or persistence of $S$. aureus in milk. Moreover, after growth of $S$. aureus in milk whey, the bacteria were very difficult to lyse by using lysostaphin (data not shown). Because lysostaphin acts on the peptidoglycan structure, this observation suggests that the peptidoglycan layer was thicker or the composition was changed. It has been reported that milk-whey-grown $S$. aureus strains were enhanced in virulence (Mamo et al., 1991). However, it has not been investigated whether this enhanced virulence was due to changes in the peptidoglycan layer.

II. The genes of the second group of mutants, SMI05, SMI06, SMI07, SMI20 and SMI32, showed identity to genes involved in nucleic acid biosynthesis. SMI05 and SMI32 showed identity to the purH gene of Bacillus cereus and SMI20 to the purD gene of Helicobacter pylori. L. monocytogenes purD and purH genes were also found to be induced in eukaryotic cells (Klarsfeld $e t$ al., 1994), and S. aureus and Streptococcus pneumoniae genes sharing homology with genes in the same biosynthetic pathway were also identified by STM (Mei et al., 1997; Coulter et al., 1998; Polissi et al., 1998). pur mutants of Salmonella and Pseudomonas were attenuated in vivo (Mahan et al., 1993; Wang et al., 1996). The gene of mutant SMI06 is homologous to the yexA gene of $B$. subtilis. yexA is a hypothetical gene of the pur operon of this organism. As discussed above, the mutants SMI05T and SMI06T had a decreased growth rate in milk whey. This suggests that pur genes play an important role during replication in milk. The sequences of mutant SMI07 were homologous to pyrP of Bacillus caldolyticus. In this organism the pyrP gene encodes a membrane transporter of pyrimidines (Ghim \& Neuhard, 1994). 
III. The third class of mutants had insertions in genes homologous to genes with a transcriptional regulatory function. The gene impaired in strain SMI02 had strong similarity at the protein level to $p h o R$ of various bacterial species. phoR encodes the sensor protein which is part of a two-component signal transduction system (Seki et al., 1988). Two-component regulatory systems play important roles in the adaptive responses of many bacteria to environmental changes (Finlay \& Falkow, 1997). The phoR/phoP operon is upregulated under phosphate-limiting conditions. Under these conditions the production of alkaline phosphatases and phosphatetransport proteins is increased by the transcriptional activator phoP. In E. coli at least 30 genes are regulated by this system (Wanner, 1993). An E. coli mutant containing a transposon insertion in the $p s t / p h o U$ region is hyperinvasive for epithelial cells (Sinai \& Bavoil, 1993), suggesting that genes of the pho regulon may be involved in pathogenesis. In Bacillus subtilis, phoR/phoP is part of a complex network of signaltransduction systems (Birkey et al., 1998). In addition, the $p h o H$ gene of $S$. pneumoniae, also part of the pho regulon, was identified by STM (Polissi et al., 1998). Therefore, the insertional mutation in strain SMI02 may have an important influence on the ability of $S$. aureus to adapt to the udder environment. Mutant SMI33 had an insertion in a gene homologous to comK of B. subtilis, which encodes a transcriptional regulator involved in genetic competence. The signals involved in competence development all converge at the level of $\operatorname{comK}$ expression (van Sinderen et al., 1995). Therefore, comK has a central role in the transition from exponential phase to the genetic competence phase of B. subtilis. Further characterization is needed to elucidate if this $S$. aureus gene also has a central regulatory function.

IV. The gene identified in mutant SMI15 showed a strong homology to a hypothetical gene of the nematode Caenorhabditis elegans and to phosphoglycolate phosphatases of various bacterial species. The product of the C. elegans gene also has homology to phosphoglycolate phosphatases of various organisms. Phosphoglycolate phosphatase is a key enzyme of glycolate metabolism in autotrophic organisms (Schaferjohann et al., 1993).

v. Two mutants, SMI44 and SMI46, had insertions in a gene which showed homology to an $S$. aureus gene encoding a protein called staphopain. Staphopain contains a domain with homology to thiol-activated proteases. This domain was also present in the identified sequences of strains SMI44 and SMI46, suggesting that this gene also encodes a thiol-activated protease. Thiolactivated proteases, or cysteine proteases, are present in both eukaryotic and prokaryotic organisms and some are known to play an important role in virulence. For instance, the speB gene of Streptococcus pyogenes encodes a cysteine protease and is a major virulence factor (Podbielski et al., 1999). Recently, a cysteine proteinase was purified from an $S$. aureus strain derived from a diseased chicken (Takeuchi et al., 1999). The Nterminal amino acid sequence of this protease was also strongly homologous to the staphopain sequence.
Nine milk-expressed genes had no sequence homology with any sequence in the databases. These mutants had different levels of $\beta$-gal expression on milk agarose plates.

\section{Concluding remarks}

Growth on milk, which partly mimics the early steps in the pathogenesis of $S$. aureus mastitis, was used for the identification of specifically expressed $S$. aureus genes. Several genes that may contribute to persistence and replication in the bovine mammary gland were identified. The significance of this in vitro strategy is further demonstrated by the observation that some of the selected genes were also found after using IVET or STM. Therefore, this in vitro approach is likely to be a fast and simple method for the selection of genes important in the pathogenesis of $S$. aureus mastitis. In addition, this model may be useful for identification of novel growth-inhibitory compounds for use as therapeutic agents for bovine mastitis.

\section{ACKNOWLEDGEMENTS}

We thank Dr A. J. M. Vriesema for critical reading of the manuscript, and Dr T. Foster for kindly providing bacteriophage 85 and $S$. aureus strain $8325-4$.

\section{REFERENCES}

Altschul, S. F., Gisch, W., Miller, W., Myers, E. W. \& Lipman, D. J. (1990). Basic local alignment search tool. J Mol Biol 215, 403-410.

Berger-Bachi, B., Strassle, A., Gustafson, J. E. \& Kayser, F. H. (1992). Mapping and characterization of multiple chromosomal factors involved in methicillin resistance in Staphylococcus aureus. Antimicrob Agents Chemother 36, 1367-1373.

Birkey, S. M., Liu, W., Zhang, X., Duggan, M. F. \& Hullet, F. M. (1998). Pho signal transduction network reveals direct transcriptional regulation of one two-component system by another two-component regulator: Bacillus subtilis phoP directly regulates production of resD. Mol Microbiol 30, 943-953.

Camilli, A., Portnoy, D. A. \& Youngman, P. (1990). Insertional mutagenesis of Listeria monocytogenes with a novel Tn917 derivative that allows direct cloning of DNA flanking transposon insertions. J Bacteriol 172, 3738-3744.

Chan, P. F. \& Foster, S. J. (1998). The role of environmental factors in the regulation of virulence-determinant expression in Staphylococcus aureus 8325-4. Microbiology 144, 2469-2479.

Cheung, A. L., Koomey, J. M., Butler, C. A., Projan, S. J. \& Fischetti, V. A. (1992). Regulation of exoprotein expression in Staphylococcus aureus by a locus (sar) distinct from agr. Proc Natl Acad Sci USA 89, 6462-6466.

Coulter, S. N., Schwan, W. R., Ng, E. Y. W. \& 7 other authors (1998). Staphylococcus aureus genetic loci impacting growth and survival in multiple infection environments. Mol Microbiol 30, 393-404.

Ehlert, K., Schroder, W. \& Labischinsky, H. (1997). Specificities of $f e m A$ and $f e m B$ for different glycine residues: FemB cannot substitute for FemA in staphylococcal peptidoglycan pentaglycine side chain formation. J Bacteriol 179, 7573-7576.

Fang, W., Shi, M., Huang, L., Shao, Q. \& Chen, J. (1993). Growth of lactobacilli, Staphylococcus aureus and Escherichia coli in normal and mastitic milk and whey. Vet Microbiol 37, 115-125. 
Finlay, B. B. \& Falkow, S. (1997). Common themes in microbial pathogenicity revisited. Microbiol Mol Biol Rev 61, 136-169.

Ghim, S. \& Neuhard, J. (1994). The pyrimidine biosynthesis operon of the thermophile Bacillus caldolyticus includes genes for uracil phosphoribosyltransferase and uracil permease. J Bacteriol 176, 3698-3707.

Klarsfeld, A. D., Goossens, P. L. \& Cossart, P. (1994). Five Listeria monocytogenes genes preferentially expressed in infected mammalian cells: plcA, purH, purD, pyrE and an arginine ABC transporter gene, arp. J Mol Microbiol 13, 585-597.

Lowe, A. M., Beattie, D. T. \& Deresiewicz, R. L. (1998). Identification of novel staphylococcal virulence genes by in vivo expression technology. Mol Microbiol 27, 967-976.

Mahan, M. J., Slauch, M. J. \& Mekalanos, J. J. (1993). Selection of bacterial genes that are specifically induced in host tissues. Science 259, 686-688.

Mamo, W., Lindahl, M. \& Jonsson, P. (1991). Enhanced virulence of Staphylococcus aureus from bovine mastitis induced by growth in milk whey. Vet Microbiol 27, 371-384.

Marquardt, J. L., Siegele, D. A., Kolter, R. \& Walsh, C. T. (1992). Cloning and sequencing of Escherichia coli mur $Z$ and purification of its product, a UDP- $N$-acetylglucosamine enolpyruvyl transferase. J Bacteriol 174, 5748-5752.

Mei, J., Nourbakhsh, F., Ford, C. W. \& Holden, D. (1997). Identification of Staphylococcus aureus virulence genes in a murine model of bacteraemia using signature-tagged mutagenesis. Mol Microbiol 26, 399-407.

Novick, R. P. (1991). Genetic systems in staphylococci. Methods Enzymol 204, 587-636.

Ohlsen, K., Koller, K. P. \& Hacker, J. (1997). Analysis of expression of the alpha-toxin gene (bla) of Staphylococcus aureus by using a chromosomally encoded hla::lacZ fusion. Infect Immun 65, 3606-3614.

Oskouian, B. \& Stewart, G. C. (1990). Repression and catabolite repression of the lactose operon of Staphylococcus aureus. J Bacteriol 172, 3804-3812.

Podbielski, A., Woischnik, M., Kreikemeyer, B., Bettenbrock, K. \& Buttaro, B. A. (1999). Cysteine protease SpeB expression in group A streptococci is influenced by the nutritional environment but SpeB does not contribute to obtaining essential nutrients. Med Microbiol Immunol 188, 99-109.

Polissi, A., Pontiggia, A., Feger, G., Altieri, M., Mottl, H., Ferrari, L. \& Simon, D. (1998). Large scale identification of virulence genes from Streptococcus pneumoniae. Infect Immun 66, 5620-5629.

Sambrook, J., Fritsch, E. F. \& Maniatis, T. (1989). Molecular Cloning: a Laboratory Manual., 2nd edn. Cold Spring Harbor, NY: Cold Spring Harbor Laboratory.

Sandgren, C. H., Mamo, W., Larsson, I., Lindahl, M. \& Björk, I. (1991). A periodate-sensitive anti-phagocytic surface structure, induced by growth in milk and milk whey, on Staphylococcus aureus isolated from bovine mastitis. Microb Pathog 11, 211-220.
Schaferjohann, J., Yoo, J. G., Kusian, B. \& Bowien, B. (1993). The $c b b$ operons of the facultative chemoautotroph Alcaligenes euthrophus encode phosphoglycolate phosphatase. J Bacteriol 175, 7329-7340.

Schenk, S. \& Laddaga, R. A. (1992). Improved method for electroporation of Staphylococcus aureus. FEMS Microbiol Lett 94, 133-138.

Seki, T., Yoshikawa, H., Takahashi, H. \& Saito, H. (1988). Nucleotide sequence of Bacillus subtilis phoR gene. J Bacteriol 170, 5935-5938.

Seligman, S. J. \& Pincus, M. R. (1987). A model for the threedimensional structure of peptidoglycan in staphylococci. $J$ Theor Biol 124, 275-292.

Sinai, A. P. \& Bavoil, P. M. (1993). Hyper-invasive mutants define a novel Pho-regulated invasion pathway in Escherichia coli. Mol Microbiol 10, 1125-1137.

van Sinderen, D., Luttinger, A., Kong, L., Dubnau, D., Venema, G. \& Hamoen, L. (1995). comK encodes the transcription competence factor, the key regulatory protein for competence development in Bacillus subtilis. Mol Microbiol 15, 455-462.

Smith, H. E., Wisselink, H. J., Vecht, U., Gielkens, A. L. J. \& Smits, M. A. (1995). High-efficiency transformation and gene inactivation in Streptococcus suis type 2. Microbiology 141, 181-188.

Sutra, L. \& Poutrel, B. (1994). Virulence factors involved in the pathogenesis of bovine intramammary infections due to Staphylococcus aureus. J Med Microbiol 40, 79-89.

Sutra, L., Rainard, P. \& Poutrel, B. (1990). Phagocytosis of mastitis isolates of Staphylococcus aureus and expression of type 5 capsular polysacharide are influenced by growth in the presence of milk. J Clin Microbiol 28, 2253-2258.

Takeuchi, S., Kinoshita, T., Kaidoh, T. \& Hashizume, N. (1999). Purification and characterization of protease produced by Staphylococcus aureus isolated from a diseased chicken. Vet Microbiol 67, 195-202.

Wang, J., Mushegian, A., Lori, S. \& Jin, S. (1996). Large-scale isolation of candidate virulence genes of Pseudomonas aeruginosa by in vivo selection. Proc Natl Acad Sci USA 93, 10434-10439.

Wanner, B. L. (1993). Gene regulation by phosphate in enteric bacteria. J Cell Biochem 51, 47-54.

Wehrmann, A., Phillipp, B., Sahm, H. \& Eggeling, L. (1998). Different modes of diaminopimelate synthesis and their role in cell wall integrity: a study with Corynebacterium glutamicum. J Bacteriol 180, 3159-3165.

Youngman, P. J. (1987). Plasmid vectors for recovering and exploiting Tn917 transpositions in Bacillus and other grampositive bacteria. In Plasmids: a Practical Approach, pp. 79-103. Edited by K. Hardy. Oxford: IRL Press.

Received 10 January 2000; accepted 12 January 2000. 